\title{
PENINGKATAN KEMAMPUAN BERBAHASA MELALUI \\ MEDIA GAMBAR ANAK KELOMPOK B I DI TKTKK TUNAS KARTINI MOYUDAN SLEMAN YOGYAKARTA
}

\author{
Supriyanti, \\ TK PKK Tunas Kartini Moyudan \\ suprimy $\bar{d}$ gmail.com
}

\begin{abstract}
Abstrak
Artikel ini membahas tentang cara meningkatkan kemampuan berbahasa melalui media gambar. Fokus kajian di lakukan di TK PKK TUNAS KARTINI Moyudan Sleman Yogyakarta dengan Pembelajaran Kemampuan membaca melalui media gambar, secara individu anak diajak untuk permainan mencocokan gambar dengan kata dan guru bertindak sebagaifasilitator. Diharapkan dengan media gambar kemampuanmembaca anak menjadi meningkat serta suasana pembelajaranmenjadimenarikdanmenyenangkan.
\end{abstract}

Kata kunci :Membaca Permulaan, Media Gambar.

\begin{abstract}
This article discusses how to improve language skills through the medium of picture. The focus of the study was conducted in TK PKK Tunas Kartini Moyudan Sleman, Yogyakarta reseach of Learning Ability to read through pictures media, individual children are invited to the game matching pictures with words and the teacher acts as a facilitator. Expected by pictures media of reading ability is enhanced and learning environment to be interesting and fun.
\end{abstract}

Keywords: Reading Starters, Pictures Media.

PENDAHULUAN

Mengajarkan bahasa bagi anak usia dini merupakan suatu hal yang penting dilakukan. Hal ini bertujuan untuk mempermudah anak dalam hal bersosialisasi dengan individu lain. Seandainya anak tidak diajarkan berbahasa sejak dini maka di masa yang akan datang, anak kan mengalami kesulitan untuk berkomunikasi dengan teman, keluarga atau orang lain. Terkait dengan bahasa terdapat 4 hal yang digunakan oleh manusia yakni mendengarkan, membaca, berbicara dan menulis. Tanpa adanya bahasa seorang anak akan kesulitan untuk mengerti sebuah maksud dan tujuan dari yang diungkapkan oleh orang lain. Sehingga perlunya berbahasa diajarkan mulai sejak dini.Diantaranya adalah pengenalan aksara seperti dalam kegiatan membaca untuk anak.

Pengenalan membaca untuk anak usia Taman Kanak-kanak (TK) penting dilakukan agar mereka dapat lebih lancar ketika memasuki jenjang pendidikan yang lebih tinggi yaitu pada jenjang Sekolah Dasar. Seperti yang diungkapkan Berko (2004), Berninger (2006), dan Rubin (2006) dalam Santrock (364: 2007) yang menyatakan bahwa anak-anak yang memasuki jenjang sekolah dasar dengan kosakata yang terbatas, beresiko mengembangkan masalah-masalah yang berkaitan dengan membaca. Pernyataan tersebut juga didukung oleh tujuan TK seperti yang dikutip dalam Pedoman Pengembangan Pembelajaran Taman Kanak-Kanak tahun 2010 yang didalamnya dijelaskan tentang tujuan TK salah satunya adalah membantu peserta didik mengembangkan berbagai potensi baik psikis dan fisik yang meliputi nilainilai agama dan moral, sosio emosional, kemandirian, kognitif, bahasa dan fisik 
motorik untuk siap memasuki pendidikan dasar. Namun porsi yang digunakan oleh pendidik untuk mengajarkan membaca dan menulis di TK dilaksanakan sesuai prinsip dari pendidikan TK sebagai sebuah taman bermain. Misalnya dengan belajar membaca dengan gambar, hal ini akan mempermudah anak untuk memahami yang ada dalam tulisan. Menurut Dipdiknas 2006.8 Pedoman membaca dan menulis ini tahap pembimbingan kemampuan membaca anak berlangsung dalam beberapa tahap membaca gambar ,tahap pengenalan baca dan tahap membaca lancar.

Dari beberapa pernyataan yang dikemukakan di atas dapat disimpulkan bahwa pengenalan membaca bagi anak TK juga penting dilakukan agar mempermudah anak untuk belajar dijenjang selanjutnya atau di Sekolah Dasar. Dari hasil pengamatan yang dilakukan oleh peneliti dalam Kelompok B 1 di TK PKK Tunas Kartini yakni kelompok anak usia 5-6 tahun diketahui bila anak langsung diajarkan menulis atau membaca tidak dengan gambar anak akan merasa kesulitan. Ada sebagian anak yang langsung bisa lancar menulis dan membaca tidak dengan gambar .

Berdasarkan pengamatan yang dilakukan oleh peneliti, maka peneliti ingin menggunakan media kartu bergambar untuk mengenalkan membaca pada anak. Isi kartu kata bergambar ini adalah gambar benda dan tulisan nama benda dibawahnya. Diharapkan menggunakan media ini anak akan lebih tertarik untuk belajar membaca dan tidak bosan dalam belajar. Seperti Menurut WJS Poerwodarminto (71: 1971) menyatakan bahwa membaca yaitu melihat sambil mengucapkan suatu tulisan dengan tujuan ingin mengetahui isinya yg dimaksud anak mampu membaca permulaan dan (pramembaca) adalah anak dapat menghubungkannya atau media gambarnya. Sehingga diharapkan proses pembelajaran membaca tidak dilakukan dengan keterpaksaan atau penekanan pada anak.

\section{TUJUAN}

Penelitian ini bertujuan untuk meningkatkan kemampuan membaca melalui penggunaan media gambar dalam pembelajaran pada anak Kelompok B 1 di TK Tunas Kartini

\section{METODE PENELITIAN \\ Jenis Penelitian}

PenelitianinimerupakanPenelitianT indakanKelas

(PTK).Penelitianinidilakukanketikakegiata npembelajaranberlangsung. Yaitu dilakukan dengan bantuan guru kelas untuk memecahkan masalah pembelajaran, kedudukan guru dalam penelitian ini berfungsi melaksanakan tindakan yang telah dirancang oleh tim peneliti atau disebut pelaku tindakan.

\section{Obyek dan Subjek Penelitian}

Subjek penelitian adalah siswa Kelompok B 1 TK PKK Tunas Kartini Moyudan dengan jumlah 15 anak yang terdiri dari 8 anak laki-laki dan 7 anak perempuan.

Objek penelitian adalah kemampuan membaca pada anak Kelompok B.

\section{Waktu dan lamanya penelitian}

Waktu penelitian selama6 bulan dimulai pada Januari 2016 sd 18 Juni 2016.

\section{Lokasi penelitian.}

Penelitian ini dilaksanakan di TK PKK Tunas Kartini yang beralamat di Tiwir, Sumbersari, Moyudan, Sleman, D. I. Yogyakarta.

\section{Prosedur}

Penelitian tindakan kelas ini dilaksanakan selama 2 siklus, setiapsiklusnya dilaksanakanselama 3 kali pertemuan. Siklus I dilaksanakan pada bulan Maret 2016 dan siklus II dilaksanakan bulan Juni 2016. Setiap 
siklus dilaksanakan dengan langkahlangkah perencanaan, pelaksanaan tindakan, pengamatan (observasi) dan refleksi.

\section{Perencanaan}

Pada tahap perencanaan ini, penulis melakukan persiapan untuk melaksanakan tindakan antara lain :

a. Menentukan masalah yang akan diparbaiki yaitu kemampuan berbahasa anak khususnya membaca.

b. Memilih alternatif yang digunakan untuk meningkatkan kemampuan berbahasa anak khususnya dalam pengenalan membaca bagi anak.

c. Menyusun skenario dan strategi untuk melaksanakan alternatif yang telah dipilih

d. Menyusun RPP terkait dengan peningkatan kemampuan berbahasa bagi anak

e. Membuat lembar kerja untuk mengetahui peningkatan kemampuan berbahasa anak khususnya dalam membaca

f. Menyiapkan Instrumen untuk melihat peningkatan kemampuan berbahasa anak

Pelaksanaan Tindakan

Pada tahap pelaksanaan ini penulis telah melaksanakan skenario perbaikan pembelajaran dengan menggunakan media pembelajaran media kartu gambar sesuai dengan RPP yang telah disusun.

Pengamatan

Pada tahap pengamatan ini dilaksanakan pada saat pelaksanaan pembelajaran menggunakan media kartu gambar. Pengamatan yang dilakukan penulis adalah pengamatan terhadap proses pembelajarannya khususnya peningkatan kemampuan berbahasa siswa dalam membaca dengan menggunakan format pengamatanyang telah disediakan. Pengamatan terhadap pengingkatan kemampuan berbahasa siswa berkaitan dengan hasil belajar dengan menggunakan instrumen test. Pengamatan peningkatan siswa ini menggunakan lembar observasi dengan indikator yaitu anak mampu mengenal suku kata (mengeja) dan anak mampu menghubungkan kata dengan gambar, kemampuan membaca siswa ini diamati dengan instrumen pengamatan chek list yang sudah disiapkan.

\section{Refleksi}

Data hasil pengamatan yang diperoleh selama proses pembelajaran berlangsungyang berupa kemampuan berbahasa anak khususnya membaca, selanjutnya data tersebutdianalisis secara diskriptif kualitatif. Berdasarkan hasil analisis ini, penulis dan kolaborator melakukan refleksi diri untuk menentukan keberhasilan penelitian dan merencanakan tindakan berikutnya. Pada tahap ini penulis juga melakukan evaluasi apakah tindakan yang dilakukan sudah sesuai dengan yangdirencanakan.Tolok ukur keberhasilannya adalah indikator keberhasilan yang telah ditentukan. Jika hasil tindakan sudah sesuai dengan indikator keberhasilan maka penelitian itu akan dihentikan,namun juga belum selesai maka penelitian ini akan dilanjutkan kesiklus berikutnya sampai semua masalah terselesaikan.

\section{Data dan Analisis Data}

Data yang dikumpulkan adalah data yang berkaitan dengan proses pelaksanaan pembelajaran yang menggunakan media kartu gambar yaitumeliputi peningkatan kemampuan berbahsa anak khususnya dalam membaca. Data proses pelaksanaan pembelajran ini dikumpulkan dengan lembar observasi yang berupa chek list. Data hasil belajar membaca anak dikumpulkan dengan menggunakan instrument test.

\section{Indikator Keberhasilan}

Indikator keberhasilan pada penelitian tindakan kelas ini adalah jika kemampuan berbahasa anak Kelompok B 1 TK PKK Tunas Kartini yang berkategori BSB (Berkembang Sangat Baik) mencapai $75 \%$. 


\section{HASIL PENELITIAN DAN \\ PEMBAHASAN \\ Hasil Penelitian}

Sebagai gambaran keadaan siswa terkait dengan perkembangan kemampuan membaca anak yang terjadi dilapangan sebelum dilakukan tindakan maka dapat dilihat seperti berikut ini

Tabel 1. Kemampuan Membaca Kelompok B1 pratindakan

\begin{tabular}{|l|l|l|}
\hline \multirow{2}{*}{ Kategori } & \multicolumn{2}{|l|}{ Kemampuan Membaca } \\
\cline { 2 - 3 } & Jumlah & Prosentase \\
\hline BB & 0 & $0 \%$ \\
\hline MB & 8 & $53,3 \%$ \\
\hline BSH & 5 & $33,3 \%$ \\
\hline BSB & 2 & $13 \%$ \\
\hline
\end{tabular}

Dari hasil pengamatan pratindakan dapat dilihat jika kemampuan membaca Kelompok B1 kategori anak mulai berkembang masih dalam presentase 53,3 $\%$. Sedangkan yang sudah bisa membaca permulaan adalah sebesar $13 \%$.

Tabel 2. Kemampuan Membaca Kelompok B1 Siklus 1

\begin{tabular}{|l|l|l|}
\hline \multirow{2}{*}{ Kategori } & \multicolumn{2}{|l|}{ Kemampuan Membaca } \\
\cline { 2 - 3 } & Jumlah & Persentase \\
\hline BB & 0 & $0 \%$ \\
\hline MB & 5 & $33,3 \%$ \\
\hline BSH & 7 & $46,7 \%$ \\
\hline BSB & 3 & $20 \%$ \\
\hline \hline
\end{tabular}

Hasil pengamatan yang telah dilakukan disiklus I terdapat peningkatan hasil dari pratindakan sebesar 13,4 \% untuk kategori BSH dan $7 \%$ untuk kategori BSB. Pada siklus I belum memenuhi indikator keberhasilan yang diinginkan maka dilakukan perbaikan pada siklus II.
Tabel 3. Kemampuan Membaca Kelompok B1 Siklus 2

\begin{tabular}{|l|l|l|}
\hline \multirow{2}{*}{ Kategori } & \multicolumn{2}{|l|}{ Kemampuan Membaca } \\
\cline { 2 - 3 } & Jumlah & Prosentase \\
\hline BB & 0 & $0 \%$ \\
\hline MB & 1 & $6,7 \%$ \\
\hline BSH & 2 & $13,3 \%$ \\
\hline BSB & 12 & $80 \%$ \\
\hline
\end{tabular}

Dari data yang diperoleh maka kemampuan membaca Kelompok B1 disiklus 2 telah meningkat sebesar $60 \%$ pada kategori BSB. Dari data tersebut peneliti merasa bahwa presentase rata-rata kemampuan membaca awal telah mencapai indikator keberhasilan yang diinginkan yakni telah mencapai lebih dari $75 \%$.

Berikut dapat dilihat peningkatan kemampuan membaca anak dari sebelum diadakan tindakan sampai selesai Siklus 2.

Tabel 4.Kemampuan Membaca pada pra tindakan, tindakan siklus 1 dan 2

\begin{tabular}{|l|l|l|l|}
\hline \multirow{2}{*}{ Kategori } & \multicolumn{3}{|c|}{ Keaktifan siswa } \\
\cline { 2 - 4 } & $\begin{array}{c}\text { Pra } \\
\text { tindakan }\end{array}$ & \multicolumn{1}{|c|}{ Siklus 1 } & Siklus 2 \\
\hline BB & $0 \%$ & $0 \%$ & $0 \%$ \\
\hline MB & $53,3 \%$ & $33,3 \%$ & $6,7 \%$ \\
\hline BSH & $33,3 \%$ & $46,3 \%$ & $13,3 \%$ \\
\hline BSB & $13,3 \%$ & $20 \%$ & $80 \%$ \\
\hline
\end{tabular}

Dari data tersebut dapat dilihat bahwa terdapat peningkatan sebesar $6,7 \%$ pada kategori BSB dari pratindakan sampai akhir Siklus I, yakni dari 13,3\% pada pratindakan menjadi $20 \%$ pada akhir Siklus I. Sedangkan dari Siklus I sampai akhir Siklus II terjadi peningkatan sebesar $60 \%$ sehingga pada akhir Siklus II diperoleh presentase sebesar $80 \%$.

\section{PEMBAHASAN}

Berdasarkan pada hasil pengamatan terhadap kemampuan 
membaca anak pada pelaksanaan pembelajaran menggunakan media kartu gambar jika dibandingkan kemampuan membaca anak dalam mengikuti pembelajaran antara pratindakan, siklus1 dan siklus 2 nampak terjadi peningkatan jumlah anak seperti yang tampak pada table 7.

Kalau melihat data tersebut diatas menunjukkan bahwa keaktifan siswa dalam mengikuti kegiatan pembelajaran mengalami peningkatan dari mulai pra tindakan ke siklus 1 maupun pada siklus 2. Adanya peningkatan kemampuan membaca siswa tersebut menunjukkan adanya partisipasi yang baik dari siswa dalam mengikuti pembelajaran. Kemampuan membaca awal merupakan keinginan ideal yang biasanya di inginkan di awal-awal sekolah dasar. Karena pelaksanaan pembelajaran yang baik hendaknya bisa dilakukan secara menyenangkan, nyaman, tidak menekan keinginan anak serta bersifat bermain sehingga merangsang anak didik untuk berpartisipasi aktif, serta memberikan ruang yang cukup bagi perkembangan kognitif serta psikologis peserta didik.

Kegiatan pembelajaran pengenalan membaca dengan kartu karta ini dapat diamati bahwa dengan kartu gambar ini anak dapat belajar kata. Anak belajar dengan cara melihat benda dalam gambar kemudian mengenali aksara penulisan gambar dengan tulisan yang tertera dalam masing-masing kartu. Pengenalan aksara ini adalah dengan menyebutkan hurufhuruf pembentuk kata pada gambar.Dari penelitian yang dilakukan telah sesuai dengan perkembangan membaca permulaan yang dikemukakan oleh WJS Poerwodarminto, yaitu bahwa membaca adalah proses kegiatan melihat sambil mengucapkan suatu tulisan dengan tujuan ingin mengetahui isinya yang dimaksud anak mampu membaca permulaan dan pra membaca adalah anak dapat menghubungkannya atau media gambarnya. Anak belajar membaca dengan melihat benda dalam gambar dan memunculkan kembali ingatannya bentukbentuk huruf yang membentuk kata sehingga anak mampu menghubungkan kata dengan gambar.

Dari perkembangan bahasa khususnya membaca anak usia dini, penelitian ini juga sesuai dengan pernyataan Santrock (2007) tentang perkembangan membaca anak usia dini khususnya di usia TK Kelompok B anak belajar membaca dengan melihat simbolsimbol serta berusaha membunyikan katakata (suku kata yang membentuk sebuah kata), setelah pembelajaran dengan menggunakan media kartu kata anak-anak belajar mengeja kata-kata yang tertera di tembok serta macam-macam kata yang ia temui. Dari pengamatan dan penelitian ini diperoleh kesimpulan bahwa anak-anak mengalami peningkatan dalam kemampuan membaca dan memiliki ketertarikan dalam belajar membaca dibandingkan sebelum dilakukan tindakan.

Peningkatan pemahaman terhadap materi yang dipelajari siswa tersebut dipengaruhi oleh adanyaketertarikan anak ketika belajar membaca dengan menggunakan kartu kata. Anak lebih mudah memahami dan mengenal huruf yang menyusun suatu kata karena media yang digunakan lebih menarik.Anak merasa tertarik dengan huruf yang dibuat pada kartu menggunakan tulisan warnawarni sehingga anak lebih mudah mengingat bunyi huruf yang menyusun kata tersebut.Hal ini dibuktikan ketika guru menanyakan kembali susunan kata kepada anak, anak langsung membunyikan kata tersebut sesuai dengan tulisannya, serta menyebutkan huruf dan suku kata yang membentuknya.

Berdasarkan pada perubahan yang terjadi pada para siswa Kelompok B1 terkait dengan peningkatan kemampuan membaca menggunakan media kartu gambar, menunjukkan bahwa penggunaan media kartu gambar cocok digunakan untuk meningkatkan kemampuan membaca anak dalam pembelajaran yang ditunjukkan dengan terjadinya kenaikan 
prosentase siswa yang tinggi dari tiap siklusnya.Begitu juga penggunaan media gambar ternyata juga bisa meningkatkan hasil belajar siswa, yang ditunjukkan juga terjadinya kenaikan prosentase hasil belajar siswa yang sudah memenuhi kriteria keberhasilan minimun yang telah ditetapkan dari siklus 1 ke siklus ke 2 . Kenaikan jumlah siswa yang memenuhi kriteria keberhasilan yang telah ditentukan menunjukkan bahwa dalam proses pembelajaran itu terjadi peningkatan pemahaman siswa terhadap materi yang dipelajari dan ini disebabkan karena media pembelajarannya bisa diterima oleh siswa.

\section{SIMPULAN DAN SARAN Simpulan}

Berdasarkan hasil penelitian dan pembahasan peneliti menyimpulkan bahwa penggunaan media gambar dalam pembelajaran dapat meningkatkan kemampuan membaca pada anak kelompok B di TK Tunas Kartini th pelajaran 2015/2016.

\section{Saran}

Berdasarkan penelitian tindakan yang telah dilakukan maka peneliti merasa ada yang kurang maksimal, yaitu jumlah variasi kartu kata yang dibuat, sehingga anak tidak dapat bermain dengan maksimal.

\section{DAFTAR PUSTAKA}

Depdikbud.1989. Kamus Besar Bahasa Indonesia. Jakarta: Balai Pustaka

Depdiknas.2000. Permainan Membaca dan Menulis di Taman Kanak-kanak. Jakarta.

Direktorat Pembinaan Taman KanakKanak dan Sekolah Dasar. 2010. Pedoman Pengembangan Program Pembelajaran Taman Kanak-kanak. Jakarta: Kemendiknas.

Mayke S. Tedja Saputra. 2001. Bermain, Mainan dan Permainan. Jakarta : PT Grasindo

Putri Pandan Wangi. 2005. Mendidik Anak Prasekolah Dasar. Pustaka

Santrock, John W. 2007. Perkembangan Anak Jilid 1, alih bahasa Mila Rachmawati \& Anna Kuswanti. Jakarta : Erlangga.

Saudiman, A. M. 1994. Jurnal 5 dan Motivasi Belajar. Jakarta: PT Raja Grafindo Persada

Syaiful Bakri Djamarah. 2002. Psikologi Belajar. Jakarta: PT Rineka Cipta

Warso, Agus. 2016. Penelitian Tindakan Kelas. Klaten: Widya Pustaka Publiher 